DOI 10.37882/2223-2982.2021.08.19

\title{
К ПРОБЛЕМЕ МОДЕРНИЗАЦИИ ТРАДИЦИОННОГО КРЕСТЬЯНСКОГО ХОЗЯЙСТВА ЮГА РОССИИ В КОНЦЕ XIX-НАЧАЛЕ ХХ ВВ. (ПО МАТЕРИАЛАМ ОБЛАСТИ ВОЙСКА ДОНСКОГО)
}

\section{ON THE PROBLEM OF MODERNIZATION OF THE TRADITIONAL PEASANT ECONOMY OF THE SOUTH OF RUSSIA IN THE LATE XIX-EARLY XX CENTURIES (BASED ON THE MATERIALS OF THE DON REGION)}

\section{Kolomeytseva}

Summary: The article considers the problems of traditional agricultural economy in the south of Russia in the post-reform period based on the materials of the peasantry of the Don Region. The main factors that influenced the development of agricultural production are highlighted, crisis phenomena are characterized, prerequisites, problems, achievements of modernization processes in the traditional agricultural sector are noted. It is shown that the natural prerequisites for modernization were provided by the industrial revolution and scientific and technological progress, the expansion of sales markets, increased demand for agricultural products, the formation of new forms of organization of production activities, the development of the land market. However, all innovations were introduced slowly; the crisis was most acute in the traditional peasant economy, which was explained by the prevailing extensive method of production, and insufficient resources of the peasantry, lack of knowledge. The work widely uses periodical printing data, materials of contemporaries of the studied period.

Keywords: Agricultural production, peasant farming, agriculture, agricultural modernization, agricultural market, Donskoy Army region, agricultural technologies.

\author{
Коломейцева Мария Андреевна \\ К.и.н., Московский государственный университет \\ имени М.В. Ломоносова \\ marijaandreeva@mail.ru
}

Аннотация: В статье рассматриваются проблемы традиционного земледельческого хозяйства на юге России в пореформенный период по материалам крестьянства Области войска Донского. Выделены основные факторы, влиявшие на развитие аграрного производства, характеризуются кризисные явления, отмечены предпосылки, проблемы, достижения модернизационных процессов в традиционном аграрном секторе. Показано, что естественные предпосылки модернизации обеспечивались промышленным переворотом и научно-техническим прогрессом, расширением рынков сбытов, повышением спроса на сельскохозяйственную продукцию, складыванием новых форм организации производственной деятельности, развитием земельного рынка. Однако все новации внедрялись медленно; наиболее остро проявлялся кризис в традиционном крестьянском хозяйстве, что объяснялось и господствующим экстенсивным способом производства, и низкой ресурсообеспеченностью крестьянства, недостатком знаний. В работе широко использованы данные периодической печати, материалы современников изучаемого периода.

Ключевые слова: аграрное производство, крестьянское хозяйство, земледелие, аграрная модернизация, сельскохозяйственный рынок, Область войска Донского, аграрные технологии.
$\mathrm{O}$ бострение аграрного вопроса в конце XIX-начале XX века, как проявление кризиса традиционной экономики в России, обозначило две ключевые проблемы: разрешение собственно земельного вопроса и модернизация сельскохозяйственного производства. Проблематика аграрной модернизации пореформенного периода остается одной из актуальных в отечественной историографии [1; 2]. Рассматриваются модели, характер, ход модернизационных процессов. Для воссоздания общей картины, понимания своеобразия и вариативности трансформации традиционного хозяйства интересно обращение к региональному аспекту [3].
Предметом исследования стали проблемы аграрной модернизации пореформенного периода в Области войска Донского, объектом - традиционное земледельческое крестьянское хозяйство. Особенности социальноэкономического развития региона определялись рядом факторов. Во-первых, исторически сложившейся спецификой поземельных отношений, сохранением системы войскового землепользования. Земли помещичьи и общинные крестьянские составляли отдельный фонд. Вовторых, Дон в составе южного хлебоэкспортного центра демонстрировал высокие темпы товаризации зернового производства. В-третьих, отмечался приток иногороднего сельского населения, активно вовлекающегося в 
аграрное производство, что способствовало развитию земельного рынка, сельскохозяйственного найма, расширению торговли. Аграрные отношения пореформенного периода развивались под влиянием двух тенденций: с одной стороны, - благоприятные предпосылки для капиталистической модернизации, с другой - нарастание кризисных явлений в традиционном хозяйстве.

В Донской области особенное беспокойство вызывало ухудшение экономического положения войскового казачества, благосостояние которого обеспечивало исправное несение службы. Проводились обследования по изучению причин хозяйственного обеднения казаков и определению мер его преодоления [4; 5], возникали дискуссии относительно форм землепользования и землевладения [6; 7]. В числе основных бед (сокращение казачьего пая, засилье края иногородними) назывались устаревшие, экстенсивные методы ведения хозяйства, нерациональное использование ресурсов. Заключалось о необходимости модернизации, разработки программы «культурных мероприятий», оказания агрономической помощи производителям [8; 9; 5].

Крестьянское хозяйство предметом отдельного рассмотрения не являлось. Однако признавалось, что экономическое положение войскового населения много лучше крестьянского [10, с. 361] в силу скудности земельного обеспечения и материальной несостоятельности последнего. Между тем масса крестьянства, для которого земледелие исторически оставалось основным видом деятельности и источником дохода, являлась одним из самых активных участников аграрного производства; в крайней степени была зависима от ситуации в секторе.

Рассмотрим характерные проблемы традиционного хозяйства. Одна из главных, признававшаяся многими исследователями неразрешимой [10, с. 212], - прямая зависимость от природно-климатических условий. Регион отличался непостоянством, резкими колебаниями погоды, большой проблемой, особенно в степных районах, оставался недостаток влаги. Погоды определяли пестроту сбора по местностям от высокого до «плохого и скудного», с зерном «тощим», годным только на корм скоту [11].

Большое значение имело качество почв. В области из всего пространства земли (около 15 млн.дес.) свыше $85 \%$ [12, с. 247] считалось пригодной для хлебопашества. В пользовании же надельного крестьянства находилось около 400 тыс., включая все виды земель; удобные перемежались с участками неудобной, на которой часто посев не возвращал даже семян. Из отдельных районов поступали жалобы на совершенно невозможное качество почв [13, с. 83]; в период реформы 1861 года отмечались случаи отказа от «малоценных» наделов [14, с. 72].
Настоящим бичом местных земледельцев являлись сельскохозяйственные вредители, как животные, так и насекомые. И если с первыми боролись путем отлова, введя его в повинность обществ, то борьба с насекомыми, проводившаяся весьма сомнительными способами (сгон с колосьев канатами, ручной сбор, приманивание птиц), чаще оставалась проигранной. Нередко сами земледельцы проявляли крайне «философическое» отношение, оставляя поля без должной обработки [20].

Методы организации и ведения хозяйства оставались традиционными. Общее землеустройство характеризовалось едиными для России проблемами - длинноземельем и черезполосностью, крайне осложнявшими работу, делавшие невыгодным, например, использование техники.

В системах земледелия единообразия не было [10, c. 210, 373]. Частично сохранялась залежная система, обеспечивавшаяся запасами пустующих войсковых земель, активно поступавших в аренду, что привлекало в область массу крестьян-переселенцев. Практиковалось двуполье со сменой запашки и толоки. Успехом можно считать введение трехполья, с оставлением паров. Однако по мере товаризации земледелия при сохранении экстенсивных методов площадь распашки прогрессивно увеличивалась за счет целинных и пустующих земель. Залежная система стала просто невозможной, пары в хозяйствах заменялись толокой, сроки последний сокращались. При малоземельи и отсутствии средств для аренды крестьяне при крайней нужде засевались свои наделы с минимальными интервалами.

Недостаточной была обеспеченность тягловой силой. Доля скотоводства неуклонно сокращалась в пользу земледелия; при нехватке кормов и выпасов крестьянам, как заключалось в источниках, с трудом удавалось вырастить собственный рабочий скот [15]. При недостатке выпасов крестьянский скот толпился на небольших общественных или арендованных участках, совершенно вытаптывал землю, что грозило девегетацией. В 80х гг. при наличии пары волов и лошади хозяйство уже считалось зажиточным; большинство имело только 1 рабочую лошадь, еще часть отрабатывали животную силу своим трудом или же арендовала скот у соседей [10, с. 361]. Сложности возникали и с обеспеченностью рабочей силой. При увеличении запашки требовались дополнительные работники; отсутствие таковых в семье вынуждало прибегать к найму, что, вкупе с арендной платой, многократно увеличивало расходы.

Общие проблемы осложнялись возрастающей степенью негативного антропогенного воздействия. В источниках отмечалось, что "хозяйств рациональных», отвечающим местным природно-климатическим условиям, на Дону - крайне мало [10, с. 211]. Интенсивная распаш- 
ка, бесконтрольная эксплуатация приводили к общему ухудшению плодородия земель. В качестве метода удобрения повсеместно практиковалась малоэффективная толока. Особенно истощались скудные крестьянские довольствия. Еще хуже обстояли дела с регулированием эксплуатации участков массы арендаторов, многие из которых с целью максимального сбора нещадно запахивали земли из года в год, превращая их в «негодные пустыри» $[10$, с. 374; 6; 16], затем оставляли и снимали новые. Между тем, площадь аренды на Дону постоянно росла. Наблюдалась и прямая деградация почв, вызванная бесконтрольной распашкой, вырубкой лесов под посевы, - образование оврагов, обнажение песков, заиление водоемов, что влекло изменение локальной экосистемы [17]. Мало заботилось население и об экологии в целом [17; 18, Лл.58-58об]. И хотя сами жители осознавали результаты: «поля и залежи повыпахали, бурьянов тьму поразсеяли, оврагами и водомоинами всю страну исполосовали» $[17$, с. 2], перспективы хозяйствования рисовались весьма печальными [8, с. 724].

Наглядным доказательством неэффективности традиционного способа хозяйствования являлись показатели урожайности - ниже средних по Европейской России [19, с.38-45.] (при том, что по показателю роста посевных площадей в начале XX в. область занимала одно из первых мест $[12$, с. $254 ; 20$, с. $17 ; 21$, с. 20; 19 , с. 2-25]). Между тем, практически исключительная ориентация крестьянства на земледельческое производство делала состояние урожая главным условием и мерилом благосостояния. С неурожаем погибали безвозвратно надежды земледельцев на получение дохода, требовалась помощь для собственного продовольствия и обсеменения [22], мелкие хозяйства приходили в упадок.

Кризисное состояние обострялось по мере сокращения фактического землепользования. О недостаточности крестьянского надела заговорили уже вскоре после реформы [10, с. 359]; к началу XX века, как и повсеместно по России, участки неуклонно сокращались вследствие прироста населения. Наиболее устойчивыми, зажиточными были хозяйства, способные купить или арендовать дополнительно землю, не ограниченные общинным наделом.

Вопросы разработки мероприятий по поднятию сельскохозяйственного производства рассматривались на уровне администрации, привлекались земские структуры (распорядительные комитеты). Однако единого плана улучшения ситуации не было. Активно проявила себя прогрессивная общественность, сельскохозяйственные общества, местные комитеты о нуждах сельскохозяйственной промышленности.

Одной из главнейших задач виделось просвещение, сторонники которого настаивали на первоочередности привития «знаний и умений», не только специфически производственных, но и экономических. Труд должен стать «осмысленным» $[8$, с. 733, 740], деятельность - рациональной [10, с. 93-94]. Ключевым инструментом просветительской работы стала пресса. Множество материалов размещалось на страницах Донских областных ведомостей: сведения о состоянии хозяйств и урожаях, разъяснялись на примерах новые технологии, «простые и дешевые способы» улучшения хозяйства и т.п. Хорошо был известен журнал Доно-Кубано-Терского общества сельского хозяйства «Юго-восточный хозяин»; получил распространение журнал «Хлебороб» Харьковского общества, ставивший своими целями развитие агрономических знаний и защиту «интересов мелкого земледельческого хозяйства и трудящегося деревенского населения» [23].

К делу распространения знаний стремились подключить школы, организовывались встречи, беседы, лекции [8, с. 751-752; 24]. В области открывались курсы, как общие сельскохозяйственные, так и по отраслям, рассчитанные, однако, преимущественно на казачье население. Намечались некоторые подвижки и в отношении крестьян. На местах при участии самих крестьянских обществ единично появлялись низшие сельскохозяйственной школы [25, с. 41; 33]. Распространением полезных знаний занимались священники; в проповедях призывалось повышать «производственную грамотность» путем знания «добытого из книг, ... что, когда можно сеять на том или ином грунте земли и чем ее удабривать» [27, с. 167].

Важную роль, в том числе в практической реализации мероприятий, сыграли общественные организации. Большая работа проводилась под началом упомянутого Доно-Кубано-Теркского общества, например, выставки по направлениям - научное, просветительское, обмена опытом, и одновременно выполнявшие роль «базара», где демонстрировались «произведения полеводства и луговодства», скот, машины, орудия, инвентарь, оборудование для переработки продуктов, действовали отделы промыслов. Общество способствовало открытию опытно-показательного поля, учреждению испытательной станции, для которой в виде своеобразных пожертвований заводами поставлялись экземпляры машин и оборудования [26]. В области было учреждено Донское общество сельского хозяйства, проводившее аналогичную работу и имевшее склад земледельческих машин и орудий.

Формировался научный подход к решению конкретных производственных задач, разработки пытались внедрить в жизнь. Широкая работа проводилась по борьбе с вредителями, организовывались особые совещания [29], пытались установить контакты с иностранными специалистами [30]. Составлялись, публиковались в прессе 
и рассылались на места инструкции о борьбе с вредителями. Ноу-хау стало внедрение механизированных устройств для сбора жуков [31], одно из которых было разработано при участии крестьянина Я. Алексеева [30].

Публиковались материалы по предотвращению и преодолению деградации почв, содержавшие, наряду с призывами к демонстрации «личного сознательного труда», описания конкретных методик. Искали способы борьбы с засухами, песками, инициировались опыты по задержанию влаги на почве и подпочвенной [217; 32; 33].

Проводилась работа по внедрению передовых (ныне - стандартных) способов обработки земли: весеннего боронования, пропашного земледелия, междурядной обработки посевов, отказа от малоэффективного посева «наволоком». Для поддержания нужд скотоводства и поднятия плодородия почв широко пропагандировалось травосеяние, инициативу всячески поддерживали местные власти. Более того, при сдачи войсковых земель в откуп предусматривалось обязательное оставление части участков под выращивание трав. Пробные посевы производились на опытных полях местными сельскохозяйственными обществами. Как отмечалось, крестьяне, еще недавно удивлявшиеся тому, что траву можно сеять целенаправленно, начинали его вводить, пусть в ограниченных масштабах и основном в хозяйствах, достаточно обеспеченных землей [15]. Одним из ключевых стал вопрос рациональной эксплуатации земельных участков, оставление части площадей под пар признавалось одним из главных правил рачительного хозяина. Решающим шагом, обеспечившим в представлении рационализаторов повышение эффективности хозяйств, должен был стать переход к многополью [8, с. 757].

Под влиянием модернизационных процессов, происходивших в стране в целом, популяризаторской деятельности, но, главное, с ростом товарного значения сельского хозяйства инновационные технологии постепенно набирали обороты. В начале XX века наметились такие подвижки, как переход отдельных и коллективных хозяйств к многополью с травосеянием.

Самым заметным результатом явилось расширение практики использования усовершенствованных орудий труда. Применение техники на полях крупных владельческих хозяйств отмечалось еще в середине XIX века [10, c. 211], в пореформенный период эта практика постепенно перенималась крестьянами - посредством покупки или аренды оборудования. В хозяйствах появляются культиваторы и, пользовавшиеся «заслуженным авторитетом» усовершенствованные плуги Рансома и Симса, конные грабли, сортировки, бороны с железными зубьями [10, с. 376], различные сеялки, в том числе для более эффективного, «набористого» рядового посева, жатвенные машины. Последние, хотя и стоили дорого (особен- но сбывавшиеся разными спекулянтам), оказывались главным подспорьем хозяина, позволяя обходиться без дополнительного, весьма разорительного найма [34]. С «большим удовольствием» были восприняты паровые молотилки, заменявшие трудоемкий, с большими потерями продукта традиционный обмолот, производившие дополнительно веяние и сортировку [10; с. 377]. И хотя показатели количества усовершенствованных орудий на душу крестьянского населения были явно недостаточными, чтобы заключать об интенсивной механизации хозяйств, общая тенденция была положительной: с 19011910 гг. статистика демонстрировала по пятилетиям рост в 1-1,5 раза [35, с. 89; 36, с. 68-69, 87-88; 37, с. 60-61, 79-80]. Основными проблемами приобретения и расширения ассортимента орудий оставались низкая финансовая обеспеченность крестьян и труднодоступность покупок, особенно в отдаленных местностях. Большое содействие оказывала потребкооперация: общества занимались выпиской, закупкой и реализацией оборудования на местах, нередко на условиях кредитов. Имелась еще одна проблема - ощутимый недостаток у земледельцев специальных знаний и опыта, отсутствие специалистов. На местной почве техника могла оказаться малоэффективной, а то и вовсе простаивала; из-за неправильной эксплуатации случались частые поломки.

Складываются новые формы экономического взаимодействия в виде разнообразных объединений - кооперативов, товариществ (кредитных, производственных, потребительских), ставшие важным шагом в переходе аграрного производства на более высокий уровень; в товариществах устранялась проблема измельчения участков с целью уравнительного землепользования, капиталовложения пайщиков создавали возможности расширения и совершенствования ресурсной базы. Роль и масштабы кооперации возрастали, хотя не обходилось и без критики [38; 39].

Активизируется земельный рынок. Особенность поземельных отношений на Дону составило широкое развитие аренды, источниками которой становились владельческие, надельные крестьянские, станичные и паевые казачьи земли. Большой массив передавался из войскового запаса, за счет чего пополнялись капиталы, шедший на внутренние нужды. Популярность аренды, открывавшей путь к самостоятельной организации производства, росла в связи с активизацией товарного земледелия. В среднем в 80-е годы каждая крестьянская семья дополнительно приарендовывала до 8 дес. земли, но особенно была востребована аренда среди иногородних поселенцев. При наличии капиталов арендаторы снимали значительные площади, засевая до 100 десятин. Именно в их среде отмечалось активное развитие предпринимательского начала [10, с. 266, 360, 368].

Еще одним характерным явлением стал рост значи- 
мости наемного труда в сельскохозяйственном производстве, использовавшегося практически на всех его этапах, в разнообразных формах - поденная работа, сезонная. Львиную долю на Дону составляли пришлые работники, т.к. коренное сельское население было занято в собственных хозяйствах. Современниками отмечалась высокая зависимость местного аграрного производства от ресурса наёмной рабочей силы [34].

Подводя итоги, следует отметить наличие предпосылок естественного развития модернизации, под влиянием меняющих условий, роста товароориентированности производства. Важно, что сторонники модернизации осознавали необходимость проведения мер, которые бы соответствовали местным условиям и менталитету крестьянства [15], демонстрировали реальную выгоду и доступность. Само население стремилось к улучшению хозяйства, но, как отмечалось в прессе, за отсутствие навыков, как это сделать - не знало [17, с. 2]. Экстенсивный путь и дедовские способы при сокращении наделов и уменьшении запасов земель переставали действовать. Решающее значение приобретал фактор личностный: один сеял по-старинки, полагаясь на удачу и хорошую погоду, другой - изыскивал новые пути: вступал в товарищество, брал в аренду землю и технику. Не хватало знаний, но было стремление. Номикосов С.Ф. считал несправедливыми обвинения земледельцев в лени и невежестве, утверждал, что сельское население Дона весьма энергично реализовывало все новое. Однако новые приемы и методы только вступали в силу, человек не имел сил и средств качественно улучшить свое хозяйство, например, снять зависимость от климата [10, с. 213, 214]. В чем заключалась основная проблема модернизации. Общество стояло перед необходимостью преодоления аграрного кризиса, но, как не настаивали на том энтузиасты, одних агрономических мероприятий было недостаточно. Агрономическая организация, находившаяся, по словам самих современников, в «самом зачаточном состоянии», хотя и способствовала преодолению «малокультурных приемов обработки земли» $[28 ;$ с. 57, 68], но не могла решить главного - очевидной недостаточности ресурсов крестьянства. Не случайно, один из исследователей Дона Е.П. Савельев отмечал, что для повышения производительности крестьянского хозяйства необходимо «умелое сочетание всех факторов производства: земли, труда, научного опыта и капитала» [28; с. 69].

\section{ЛИТЕРАТУРА}

1. Аграрная модернизация России в XIX - XXI вв.: Реформы, проблемы, перспективы. Сб.ст. Под общ.ред. А.В. Федоровой. - Оренбург, 2012. - 428 с.

2. Гаврилов А.В. Современная историография проблемы модернизации сельского хозяйства России второй половины XIX - начала XX века // Самарский научный вестник. научный журнал: Том 6. - 2017. - №2 (19). - С.186-192.

3. Региональное измерение аграрной модернизации в России: материалы VIII Всероссийской (XVI региональной) с международным участием конференции историков-аграрников (реднего Поволжья (г. Саранск, 16-17 сентября 2020 г.). Отв. ред. Г.А. Куршева; НИИ гуманитарных наук при Правительстве Республики Мордовия. - Саранск, 2020. - 664 с.

4. Маслаковец Н.А. 0 занятиях высочайше учрежденной 16-го июня 1898 года. Комиссии в области войска Донского и о достигнутых ею результатах: Доклад состоящего в распоряжении военного министра Генерального штаба генерал-лейтенанта Маслаковца 23 авг. 1899 г. - СПб.: типография И.Н. Скороходова, 1899. - 123 с.

5. Богачев В. По поводу обследования станичных юртов // Донские областные ведомости (далее - ДОВ). - 1908. - №4 (5 января). - С.2-3.

6. Елисеев А. К вопросу землепользования на Дону (голос земледельца) // ДОВ. - 1908. - №58 (12 марта). - С.2-3.

7. А. Гр-в «За и против (К судьбе земельной общины на Дону)» // ДОВ. - 1908. - №80 (8 апреля). - С.2-3.

8. Овчинников Н.Г. Как можно улучшить донской казак свое хозяйство // Хозяйство на Дону: еженедельный журнал по сельскому хозяйству и всем отраслям его: издаваемый Областным войска Донского Правлением. - 1912. - №30. - С. $722-777$

9. Греков А. Что же дальше? (К итогам юртовых обследований) // ДОВ. - 1908. - №11 (13 января). - С.2-3.

10. Статистическое описание Области Войска Донского. Составитель член-секретарь Областного войска Донского статистического комитета С. Номикосов. Новочеркасск: Обл.в.Д.Тип., 1884. - 744 с.

11. Местный отдел. Итоги урожая на Дону в настоящем 1908 году // ДОВ. - 1908. - №189 (4 сентября). - С.2.

12. Памятная книжка Области войска Донского (далее - ПК ОвД) на 1892. - Новочеркасск, 1892. - 407 с.

13. Тимощенков И. ІІ Донской округ Области войска Донского. Статистико-экономический очерк // СОВДСК. - 1906. - Вып.6. - С. 83-106.

14. Тимощенков И. Сидорская волость (Усть-Медведицкого округа). Статистико-этнографический очерк // СОВДСК. - 1905. - Вып.5. - С.66-81.

15. А.Г. К борьбе с дороговизной продуктов // ДОВ. - 1908. - №63 (18 марта). - С.2-3.

16. Местный отдел. Хищническая эксплуатация станичной общественной земли // ДОВ. - 1908. - №136 (27 июня). - С.3.

17. Богачев В. Необходимость задержания влаги в почве и укреплении оврагов (К вопросу об улучшении казачьего землепользования) // Д0В. - 1908. №81 (9 апреля). - (.2-3.

18. Государственный архив Ростовской области (ГАРО), Ф.52, 0п.1, Д.35.

19. Сборник статистико-экономических сведений по сельскому хозяйству России и иностранных государств. 1907-1917. - Год 1-й. - Петроград: Тип. Ис. Ф. Вайсберга, 1907. - 330 с. 
20. ПК ОвД на 1905. - Новочеркасск, 1905. - 612 с.

21. ПК ОвД на 1910. - Новочеркасск, 1910. - 622 с.

22. Результаты продовольственной кампании на Дону 1907-1908 гг. (Из общего отчета областного земского комитета // ДОВ. - 1908. - №248 (19 ноября). C.3.

23. Хлибороб // Юго-восточный хозяин журнал Доно-Кубано-Терского общества сельского хозяйства. - 1909. - №1 (1 января). - С.83.

24. Кушныренко-Кушнырев М.А. Краткий обзор сельскохозяйственного промысла за 1913 год в Области Войска Донского. - Новочеркасск: Тип. «Донской печатник», 1914. -245 c.

25. Заседание Совета Императорского Доно-Кубано-Теркского С.-Хоз. Общества // Юго-восточный хозяин журнал Доно-Кубано-Терского общества сельского хозяйства. - 1909. - №1 (1 января). - С.41-43.

26. По округам области. Ростовский округ. // ДОВ. - 1908. - №234 (1 ноября). - С.3.

27. Свящ. Томилин В. Поучение к прихожанам. 0 пользе грамотности // Донские епархиальные ведомости. - 1870. - №6 (15 марта). - С.166-170.

28. Савельев Е.П. Исторический очерк о жизни и деятельности Донского общества сельского хозяйства за 25 лет: 18 янв. 1889 - 18 янв. 1914 г. - Новочеркасск, 1913 г. -49 с.

29. Траилин П.Ф. К съезду по борьбе с хлебными жуками // ДОВ. - 1908. - №40 (17 февраля). - С.3-4.

30. П.Ф.Т. Сельскохозяйственные заметки. К борьбе с вредителями сельского хозяйства // ДОВ. - 1908. - №26 (31 января). - С.3.

31. Сторожил. Местный отдел. По поводу жуколовок // ДОВ. - 1908. - №50 (2 марта). - С.2-3.

32. Местный отдел. 0 борьбе с сыпучими песками в Донской области // ДОВ. - 1908. - №44 (22 февраля). - С.3.

33. Г-в. К борьбе с засухами // ДОВ. - 1908. - №151 (15 июля). - С.3.;

34. Шурунов И. Наше сельское хозяйство в Миусском округе, близ Азовского моря // ДОВ. - 1874. - №96. - С.2-3

35. Отчет Войскового наказного атамана о состоянии области Войска Донского за 1900 год. Ч. 2: Часть гражданская. - Новочеркасск, 1901. - 97 с.

36. Отчет Войскового наказного атамана о состоянии области Войска Донского за 1905 год. Ч. 2: Часть гражданская. - Новочеркасск, 1906. - 95 с.

37. Отчет Войскового наказного атамана о состоянии области Войска Донского за 1910 год. Ч. 2: Часть гражданская. - Новочеркасск, 1911. - 87 с.

38. Черкасцев Н.К вопросу о борьбе с дороговизною жизни // ДОВ. - 1908. - №192 (7 сентября). - С.2.

39. Скромный. По поводу вопроса о борьбе с дороговизною жизни // ДОВ. - 1908. - №226 (20 октября). - С.4-5.

(c) Коломейцева Мария Андреевна (marijaandreeva@mail.ru).

Журнал «Современная наука: актуальные проблемы теории и практики»

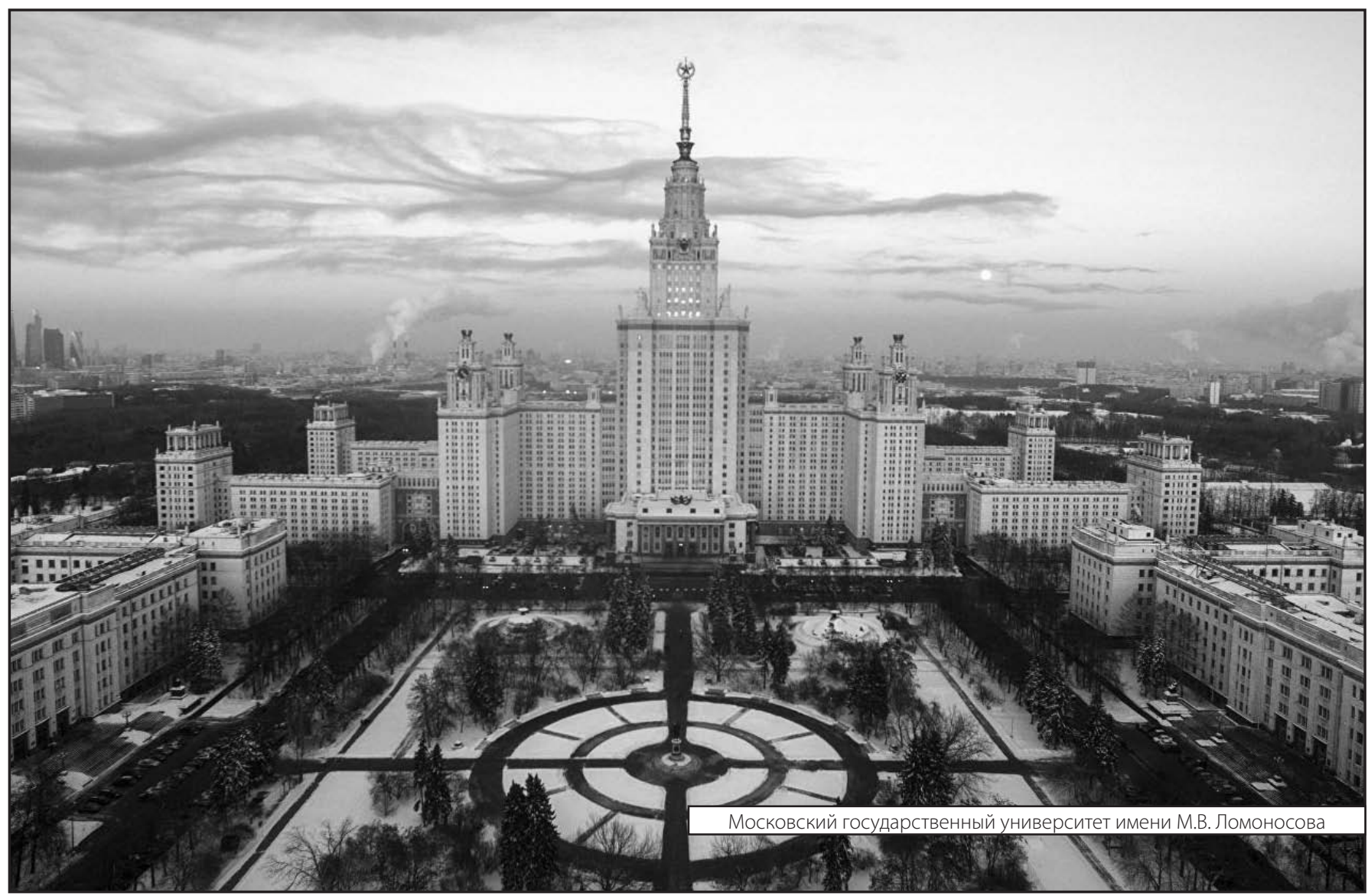

